DOI dx.doi.org/10.24866/7444-4707-6/321-327

О.В. Полохин

\title{
СПЕЦИФИКА ПОЧВООБРАЗОВАНИЯ
} НА ВНЕШНИХ ОТВАЛАХ ПОРОД ПАВЛОВСКОГО БУРОУГОЛЬНОГО МЕСТОРОЖДЕНИЯ

На территории Приморского края активно ведутся работы по добыче полезных ископаемых. При этом происходит неизбежное частичное или полное уничтожение не только верхних горизонтов почвы, но и литогенной основы. При открытой разработке месторождений, которая является основной в крае, на территориях разрезов формируются, в основном, внешние отвалы вскрышных и вмещающих пород и карьеры. Площадь занимаемая внешними отвалами достигает $60 \%$ от площади разреза $[2,3,4]$. Отвалы представляют собой различного типа возвышенности. Пространственное сочетание склоновых поверхностей данных техногенных образований можно рассматривать и изучать как катены $[6,7]$. Они построены из элементарных ландшафтов на автономных возвышенностях (элювиальные ландшафты) и до ландшафтов зон конечной аккумуляции (аккумулятивные ландшафты). Большая часть отвалов, в современных условиях проходит, в лучшем случае, этап технической рекультивации при отсутствии биологического этапа и остается под самозарастание.

Изучение процессов, происходящих при естественном возобновлении почвообразования, является не только актуальной фундаментальной задачей почвоведения, но и позволяет прогнозировать последствия применяемых технологий и способов рекультивации, что необходимо при создании безопасных для человека и окружающей среды зон $[5,10]$. Цель исследований состояла в определении особенностей формирования почвенного покрова на самозарастающих отвалах. Для этого решались задачи по определению химических, физических, физико-химических свойств почв, на различных позициях развивающихся техногенных катен.

В ходе исследований изучались почвы, сформированные на внешнем 30-35 летнем отвале участка «Северный», разработанного в 1985-1994 г.г. угольного разреза «Павловский» (разрезоуправление «Новошахтинское» ООО «Приморскуголь» АО «СУЭК»). На разрезе добывается бурый уголь 
открытым способом. Отвалы находятся в 600 м на юго-восток от дороги, ведущей в п. Новошахтинский (Приморский край, Михайловский район). Данный отвал формировался железнодорожным и автомобильным способами, был частично спланирован. Высота отвала 12-13 метров. Для выполнения поставленных задач был заложен катенарный профиль с выделением элементарных ландшафтов. Почвенные разрезы были заложены на типичных участках элементарного элювиального ландшафта, трансаккумулятивного и аккумулятивного элементарных ландшафтов. Описание почвенного профиля по морфологическим признакам производили в ходе полевых почвенных исследований. Определение гранулометрического состава выполнялось по методу Н.А. Качинского [8].

Определение общего органического углерода было произведено по методу Тюрина в модификации ЦИАО (ГОСТ 26213-91) [1], определение $\mathrm{pH}$ почвенной водной суспензии произведено потенциометрически, плотность сложения почвы - объемно-весовым методом [8]. В работе использовали субстантивную профильно-генетическую классификацию почв техногенных ландшафтов [2, 3].

Климат в районе исследования континентальный с муссонными чертами. Безморозный период длится 150-160 дней. По влагообеспеченности район является влажным. Гидротермический коэффициент 1,6-2. Годовое количество осадков 500-700 мм, из которых 9-17\% выпадает в зимний период [11].

При добыче бурого угля открытым способом производится транспортировка вскрышных и вмещающих пород в породные отвалы. При этом отвалообразование осуществляется не селективным способом. Это приводит к смешению пород, различных по петрографическому и минералогическому составам. Субстрат, слагающий отвалы, в дальнейшем выступает в роли почвообразующих пород. Изучаемый отвал с западной стороны граничит с обводным каналом, заполненным водой, который является здесь зоной конечной аккумуляции. С трех других сторон находятся отвалы вскрышных и вмещающих пород с карьерными выемками. Вскрышные породы представлены разнозернистыми слабосцементированными песчаниками, аллювиальными песчано-галечниковыми отложениями суйфунской свиты, четвертичными глинами, аргиллитами, алевролитами, и пластами угля усть-давыдовской свиты. Актуальная кислотность пород от кислой до слабокислой. Степень насыщенности пород основаниями 61-84\%. Гранулометрический состав пород от 
среднесуглинистого до среднеглинистого. Эти породы медленно преобразуются в условиях гипергенеза и малоподатливы к внутрипрофильной дифференциации.

Разрез Л 11-15. Заложен на юго-западном склоне (угол уклона 1-3º) участка элювиального ландшафта. Мезорельеф с мелкими буграми, рытвинами, неглубокими оврагами. Микрорельеф просадочно-насаженный с блюдцами и западинами. Древесная растительность представлена осиной дрожащей. Кроме нее в подросте присутствует боярышник Максимовича. Среди травянистой растительности доминирует хвощ полевой с отдельными экземплярами осок, клевера лугового, синюхи рыхлоцветковой, мышинным горошком и полынями. Общее проективное покрытие трав составляет 20$50 \%$. Формула профиля почвы O (0-1 см) - Ао (1-2,5 см) - C1 (2,5-8 см) - С2 (8-20 см) - С3 (20-60 см). Грубогумусовый горизонт порошистый, представляет собой смесь органических остатков со слабо прокрашенной минеральной частью. Переходный горизонт не выделяется. Нижележащие слои выделяются по количеству корней и плотности. Почва определена как эмбриозем органо-аккумулятивный иллювиально-гумусовый.

Анализ гранулометрического состава мелкозема показал, что грубогумусовый горизонт тяжелосуглинистый. В нижерасположенных слоях легко и среднеглинистый.

Плотность сложения почвы изменятся от 0,85 г/см3 в грубогумусовом горизонте до 1,18-1,25 г/см3 в нижележащих слоях (табл.). Величина $\mathrm{pH}$ опада - 5,91. Верхний горизонт слабокислый (рНводн. - 6,22). В нижних слоях значения $\mathrm{pH}$ снижаются до 5,87 .

В грубогумусовом горизонте количество общего органического углерода составляет 2,34\%. В нижележащих слоях его содержание резко уменьшается до значений 0,26-0,62\%. Характер распределения соответствует аккумулятивному типу. Тип гумуса гуматно-фульватный.

Разрез Л 12-14. Заложен на площадке в средней части катены (трансаккумулятивный элементарный ландшафт), представляющей собой северозападный склон крутизной $3-5^{\circ}$. В древесной растительности преобладает осина дрожащая с березой плосколистной. Кустарники представлены жимолостью Рупрехта. В травянистом ярусе доминирует хвощ полевой с единичными растениями осоки низенькой, репяшка клейкого, девясила японского, мятлика Скворцова. Общее проективное покрытие трав до 50\%. Профиль почвы имеет следующее строение О (0-1 см) - Ао(1-4 см) - АВ (4-9 см) - С1 (9-21 см) - C2g (21-60 см). Грубогумусовый горизонт по структуре мелко- 
зернисто-пылеватый. В нем отмечается много корней, микоризы. Переходный горизонт пылевато-бесструктурный. Вниз по профилю наблюдаются явления оглеенности. Тип почвы определяется как эмбриозем грубогумусовый (кустарничково-корневой) иллювиально-гумусовый глееватый.

\section{Свойства эмбриоземов техногенной катены}

\begin{tabular}{|c|c|c|c|}
\hline $\begin{array}{l}\text { Горизонт, } \\
\text { глубина, см }\end{array}$ & $\mathrm{pH}_{\text {водн. }}$ & $\mathrm{dv}, \Gamma / \mathrm{cm}^{3}$ & $\mathrm{C}_{\mathrm{opr}}, \%$ \\
\hline \multicolumn{4}{|c|}{ Элювиальная позиция } \\
\hline Ao $1-2,5$ & 6,22 & 0,85 & 2,34 \\
\hline C1 2,5-8 & 6,34 & 1,25 & 0,61 \\
\hline C2 8-20 & 6,14 & 1,18 & 0,52 \\
\hline C3 20-60 & 5,87 & 1,26 & 0,26 \\
\hline \multicolumn{4}{|c|}{ Трансаккумулятивная позиция } \\
\hline Ao 1-4 & 5,74 & 0,57 & 3,84 \\
\hline AB 4-9 & 5,92 & 1,24 & 1,07 \\
\hline C1 9-21 & 5,86 & 1,26 & 0,65 \\
\hline C2g 21-60 & 5,74 & 1,28 & 0,52 \\
\hline \multicolumn{4}{|c|}{ Аккумулятивная позиция. } \\
\hline Ao $0,5-2$ & 5,55 & 1,19 & 1,1 \\
\hline C1g 2-16 & 5,85 & 1,26 & 0,82 \\
\hline C2g 16-60 & 5,68 & 1,47 & 0,33 \\
\hline
\end{tabular}

В верхней части профиля горизонты тяжелосуглинистые. Нижележащие слои средне глинистые. Это свидетельствует о том, что в результате лессиважа минимальное содержание фракции физической глины перемещается в более глубокие слои. Содержание же фракций илистых частиц при этом увеличивается, что может свидетельствовать о процессах не только физической, но и педогенной дезинтеграции пород, слагающих отвал. Коэффициент степени дифференциации почвенного профиля, определяемый как отношение содержания илистых частиц в горизонте вмывания к содержанию ила в горизонте Ао, составляет 3,06 [9]. Это говорит о резко дифференцированном профиле.

По плотности сложения верхний горизонт вспушенный $\left(0,57 \Gamma / \mathrm{cm}^{3}\right)$. Нижележащие горизонты уплотнены. Плотность сложения в них резко возрастает до 1,28 г/ $\mathrm{cm}^{3}$.

Опад по величине актуальной кислотности и почвенные горизонты слабокислые, дифференциации не наблюдается. Содержание органического вещества в верхнем 0-2 см горизонте составляет $3,84 \%$ с резким уменьшением вниз по профилю. Гумус гуматно-фульватный.

Разрез Л 13-14. Заложен в нижней части отвала (аккумулятивный элементарный ландшафт). Древесный ярус представлен осиной и 4 видами 
ив. Древостой пройден низовыми пожарами. Из кустарников отмечены крушина даурская, рябинник рябинолистный, бересклет малоцветковый. В травяном ярусе доминирует хвощ полевой (85\%). Проективное покрытие $30 \%$. Профиль почвы имеет следующее строение: О (0-0,5 см) - Ао (0,52 см) - C1g (2-16 см) - C2g (16-60 см) (табл.). Тип почвы - эмбриозем органо-аккумулятивный иллювиально-гумусовый глееватый.

Верхний горизонт по гранулометрическому составу тяжелосуглинистый, порошистой структуры. По гранулометрическому составу они определяются как средне глинистые.

Плотность сложения в слое $0-10$ см составляет $1,17-1,19$ г/ $\mathrm{cm}^{3}$, ниже происходит резкое увеличение до значений $1,42-1,47$ г $/ \mathrm{cm}^{3}$. По величине $\mathrm{pH}_{\text {водн. }}$ - кислые, с увеличением кислотности вниз по профилю.

Содержание $\mathrm{C}_{\text {орг }}$ изменяется от $1,1 \%$ до 0,5\% вниз по профилю. Кривая распределения общего органического углерода по профилю имеет вогнутый характер с резким падением с глубиной (аккумулятивный тип распределения). В групповом составе гумусовых кислот преобладают фульвокислоты, содержание которых увеличивается вниз по профилю. Тип гумуса гуматно-фульватный.

В морфологическом отношении эти типы эмбриоземов имеют черты как сходства, так и различия [2, 3].

Сходны они в том, что имеют малую мощность почвенного профиля и слабую степень морфологической дифференциации почвенного профиля на генетические горизонты.

Различаются при этом главным образом по морфологическим признакам.

Следует отметить, что эмбриоземы грубогумусовые сформированы под лесной растительностью. В почвенном профиле помимо лесной подстилки выделяется органо-аккумулятивный горизонт с грубым гумусом. Он имеет малую мощность. Слабая степень преобразованности органического вещества обусловлена низким количеством организмов-деструкторов и кислым составом растительного опада.

В развивающихся техногенных катенах на элементарных ландшафтах дифференциация по физическим, физико-химическим и химическим свойствам выявлена в корнеобитаемом (0-20 см) слое. Переходные горизонты трудноопределяемые при морфологическом исследовании. Это объяснятся с одной стороны слабым развитием педогенных процессов почвообразования, а 
с другой - высоким содержанием углистых частиц в породах, слагающих отвалы. Кривая распределения общего органического углерода по профилю имеет вогнутый характер с резким падением с глубиной (аккумулятивный тип распределения), грубогумусовый тип профиля по Александровой Л.Н..

Тонкие фракции мелкозема в эмбриоземах, по большей части, унаследованы от вскрышных пород. Полагаем, что процессы внутрипочвенного оглинивания на ранних стадиях педогенеза (эмбриоземообразования) практически отсутствуют. Подобного мнения придерживаются и другие исследователи [3].

Накопление мелкозема осуществляется за счет физического выветривания. Однако, полностью отрицать наличие внутрипочвенного химического или биохимического выветривания нельзя. Агенты и условия для такого выветривания имеются. Однако, в силу малого времени жизни отвалов вклад внутрипочвенного выветривания обломочного материала, содержащегося в исходных почвообразующих породах, невелик.

В результате исследований установлено, что наиболее заметные педогенные преобразования исходной толщи пород наблюдаются в почвах, развивающихся на элементарных трансаккумулятивных ландшафтах.

При этом специфика формирования эмбриоземов определяется особенностями биогенных процессов, которые контролируются условиями среды, формируемыми в фазу техногенеза. Создаваемая литогенная основа отвалов (техногенных ландшафтов) определяет их дальнейшее развитие и почвенно-экологическое состояние.

\section{Литература}

1. Агрохимические методы исследования почв. - М.: Изд.-во Наука, 1975.

2. Андроханов В.А. Проблемы рекультивации техногенных экосистем Красноярского края /В.А. Андроханов, В.Г. Двуреческий // Известия ИГУ. Серия “Биология. Экология”. - 2013. - Т.6., №2. - С. 153-158.

3. Андроханов В.А. Курачев В.М. Почвенно-экологическое состояние техногенных ландшафтов: динамика и оценка / В.А. Андроханов, В.М. Курачев // Рос. акад. наук, Сиб. отд-ние, Ин-т почвоведения и агрохимии. Новосибирск: Изд-во СО РАН, 2010. - 224 с.

4. Двуреченский В. Г. Почвенно-экологическое состояние техногенных ландшафтов Новокузнецкого промышленного комплекса / В.Г. Дву- 
реченский, В.А. Андроханов // «Живые и биокосные системы». - 2017. № 20; URL: http://www.jbks.ru/archive/issue-20/article-3

5. Двуреченский В.Г. Сравнительная характеристика фракционного и группового состава гумуса в эмбриоземах техногенных ландшафтов горно-таежного пояса Кузбасса / В.Г. Двуреченский, В.П. Середина // Сибирский экологический журнал. - 2015. -Т. 22. - № 6. - С. 952-965.

6. Полохин О.В. Сингенетичность почв и растительности техногенных ландшафтов юга Приморья / О.В. Полохин, Л.Н. Пуртова, Л.А. Сибирина, С.В. Клышевская // Естественные и технические науки. - 2010. №5. - С. 164-166.

7. Полохин О.В. Специфика преобразования минеральных форм фосфатов при почвообразовании в техногенных ландшафтах / О.В. Полохин // Сибирский экологический журнал. - 2007. - № 5. - С. 843-847

8. Практикум по почвоведению / Под ред. И.С. Кауричева. - М.: Колос, 1980. - 272 с.

9. Розанов Б.Г. Генетическая морфология почв / Б.Г. Розанов. - М., Изд-во МГУ, 1975. - 284 с.

10. Соколов Д.А., Андроханов В.А., Кулижский С.П., Доможакова Е.А., Лойко С.В. Морфогенетическая диагностика процессов почвообразования на отвалах каменноугольных разрезов Сибири / Д.А. Соколов, В.А. Андроханов, С.П. Кулижский, Е.А. Доможакова, С.В. Лойко С. // Почвоведение. - 2015. - № 1. - С. 106-117.

11. Polokhin O.V. Trace elements in the soils of the man-made landscapes in Primorsky Territory / O.V. Polokhin // Международный научноисследовательский журнал. - 2016. - № 2-3 (44). - С. 36-38. 